For a full list of related titles, and for other reviews which we do not have space to print, visit our website www.theidm.com or phone the IDM on 0208614 0274

\section{Lucid and comprehensive}

\section{Thirty years of history}

\section{Lessons learned?}

\author{
The need for \\ proactivity
}

\section{Reviews}

\section{A Guide to the Data Protection Act 1998 for Direct Marketers}

\author{
Colin Fricker \\ Direct Marketing Association (UK), 2001; softback; 71pp; $£ 75$ to DMA \\ members, $£ 150$ to non-members
}

Colin Fricker has recently retired as director of government and legal affairs for the UK DMA. The comprehensive lucidity of this booklet demonstrates how much he will be missed. There is a generous recognition of help received from other parties (including the Data Protection Commissioner, whose imprimatur is invaluable) but the final product is worthy of the author's long and distinguished career.

The booklet manages to square one particular circle rather well: while it specifically draws attention to the changes which the 1998 Act makes to the 1984 Act (with which most current readers may be supposed to be familiar), it is also so constructed that newcomers to the industry, of whom there will be very many in succeeding years, should have no difficulty in following it. This is a publication that every direct marketer should first read from cover to cover, and then keep on an accessible shelf as a prime source of reference.

The introduction gives us a brief reminder of the long history of data protection in the UK, from the report of the Younger Committee on Privacy in 1972 through the 1984 Act, to this Act of 1998 based on the EU Directive on Data Protection of 1995. Over nearly 30 years of debate on this issue, the industry has had to fight a series of lengthy and costly battles against ignorance, misunderstanding and occasional malice in order to secure a position no more onerous than could, and should, have been provided for by a sensible code of practice in the first place. (The reviewer makes no mention of the cost to the public purse, both past and continuing.) And in these battles Colin Fricker, as director of legal and regulatory affairs for the DMA, played a vital part.

From these battles the industry has, one must fervently hope, learned some lessons for the future. (And perhaps the EU Commission has as well.) Certainly it is an industry much stronger and better equipped, both in the UK and in Europe, than it was 30 years ago. Both the DMA in the UK and FEDMA in Europe owe their existence (long overdue when it came about) to the need to form a coherent front against the destructive tendencies of the directive's first draft, coupled with the Data Protection Commission's failure to consult with business and industry.

But the DMA and FEDMA were formed, necessarily in the circumstances of the time, as reactive bodies struggling to hold a defensive line. What is required now is a proactive attitude to issues of industry regulation. There is evidence that, in the burgeoning field of ebusiness, the industry is indeed making serious efforts to take the lead, and to demonstrate the inherent superiority of self-regulation over 
legislation. That is the first (the only serious) battle we have yet lost over data protection. We must not lose it again over e-business.

Robin Fairlie F IDM

\section{Optimising E-Brand Profitability: Launching, Growing and Protecting Your Brand Online}

\section{Kris Wadia}

Financial Times - Prentice Hall (Imprint of Pearson Education), London, 2001; softback; ISBN 027365490 X; 119pp; £120

This is a comprehensive guide to taking your brand online, or creating an online brand. Kris is an associate partner at Accenture, and has drawn upon that company's experience of helping companies market in the e-world.

\section{A short textbook}

\section{Lack of examples}

\section{An ideal online introduction}

The style of the guide is textbook, though it is a short one. It is carefully sectioned, with the three main chapters following the life cycle of an e-brand: launch, growth and then protecting the brand. It has plenty of checklists, which will be very helpful to managers who need to make sure that their e-brand plans cover all the opportunities and risks. By and large, jargon is avoided (though there are a few purple passages), and the style is fluent.

One weakness is that no brands are mentioned by name, and no real examples are given. However, this is understandable in a world in which success today is no guarantee of success tomorrow. Also, like all consultants, Kris has to be careful about whom he compliments and whom he criticises - one never knows who will be one's clients and who one's client's competitors tomorrow!

The short prologue covers the most basic questions, what is a brand and what is brand equity, to remind us that branding has various definitions, but that the most important common factor is creating something that has financial value to the owner of the brand. The second chapter, on launching an e-brand, explains the existence of brands and why real and online worlds create different branding needs. This is followed by exploration of different tactics and strategies for brand creation. Here, the guide makes no assumption about what the reader knows, and goes right down to the basics. This approach, which is followed throughout the guide, makes it ideal introductory reading for the marketer who is suddenly asked to take up an online responsibility.

The chapters on growing and defending an e-brand explain the principles well and show how their application varies for different kinds of product and different channels. The section covering online measurement is particularly valuable, though here as elsewhere in the guide a more formal link to the wider branding knowledge base would have been helpful.

The guide by and large avoids the dreadful hype that characterises the most popular American works covering the same ground, so it will be well accepted by readers in the Old World (in the geographic sense), 


\section{No bibliography; good glossary}

\section{A historical curiosity?}

\section{A record of negatives as well as positives}

although the subtitles occasionally stray into the American style. One significant weakness is that very little empirical information is provided. Obviously, some of this would date, but reference to the research studies of say, Hewson, on the difficulties brand owners have in maintaining service standards (for example in e-mail management) and the reasons for this would have been helpful, as would a bibliography. However, this weakness is amply compensated for by a good glossary of terms.

The reviewer therefore recommends this guide to managers who are new to e-marketing (and perhaps to those who are not so new but would like to make sure that they are 'covering the ground' in their planning and management). As an introduction for students of interactive marketing, it fits the bill well, though not as an academic introduction, as its style is completely prescriptive, and the approach is one of breadth rather than depth.

Merlin Stone M IDM IBM Professor of Relationship Marketing, Bristol Business School

\section{Clicks, Bricks and Brands}

\section{Martin Lindstrom}

Kogan Page, 2001; hardback; 301pp; £25; ISBN: 0749434902

Even the publisher's blurb records that the life-span of books about e-business is four months. Fitting, then, that the author of Clicks, Bricks and Brands signed off his acknowledgments in February 2001 against a publication date of June. What we are exposed to here is the way e-commerce and e-tailing looked last winter; it may already be a historical curiosity.

There is nothing disparaging about that observation. We are beyond the days when management books sat on shelves behind desks, regularly referred to with post-it notes punctuating the more valuable pages. Authors are now commentators, not theologians or even analysts. The style is - has to be - breathless, the content assembled rather than gleaned, the predictions gloriously contradictory, the research patched in from any published source. The author, after all, is probably halfway through his next book.

The reviewer is sure that $\mathrm{Mr}$ Lindstrom is. At age 31 he has several such books behind him. He founded BBDO Interactive Europe seven years ago, cloned it in Australia in 1997 and now sits on the board of five leading Internet companies. Not bad for a bloke who was born in a Danish village called Skive.

But the new book at least carves out distinctive territory — the marriage, or at least the courtship, between offline and online businesses - 'clicks and mortar' as we must learn to call the phenomenon. It is honest enough to reveal as many negatives as positives, to record the many false dawns already experienced. Christmas 1999 in the USA was going to be an e-carnival - queue-free shopping, large product selections, cheap prices, rapid delivery. But the carnival was over quite 


\section{Rhetoric plus facts}

\section{A rushed publication let down by poor editing}

\section{A happy ragbag}

\section{Stay in touch online}

soon, with customers frustrated by overlong downloading time, delivery problems on key products and half-hour waits on telephone lines to explore the confusion. Only 74 per cent of deliveries were made on time. The brave new world was still on hold.

It is this punctuation of e-rhetoric with dire marketing facts that makes the book almost charming. Early on the author records his belief that 'by 200525 per cent of all FMCG purchases will be online'. A few pages on he declaims 'eventually we'll even buy cars online without test-driving them first'. This is wide-eyed to a fault, the sort of woozy stuff that has plagued every seminar on the subject since 1995 . Sixty pages later he is examining the brute fact that no one seems to be making money out of this revolution. The reasons are distinctly old-fashioned - savage competitive discounting, high fulfilment costs, lousy inventory management. Old mail-order hands may be permitted a knowing sneer.

An accidentally honest book, then, with the rush to publication apparently ruling out an editing process that might have consolidated a directive point of view or ironed out some of the blatant statistical contradictions it includes. Significantly, there is no index and the case histories - Amazon, Tesco, Nokia and a few of the other usual suspects - are disturbingly out of date. There again, an editor might have spared the author the Bad Taste in a Management Textbook Award by excising the example on page 190 where the heavily promoted replacement of mothers' breast milk by milk formula products in the third world is offered as an example of the MSP (me selling proposition) being replaced by the BSP (brand selling proposition). Perhaps malnutrition will be listed as a weakness on Nestlé's latest SWOT analysis?

But there is little point in being pompous about Clicks, Bricks and Brands. It is a happy ragbag of opinion, fact, anecdote, research and prediction. It is good fodder for the e-enthusiast, yet properly instructive for the e-sceptic. And if its thesis is no more profound than that 'online and offline partners should bring their mutually exclusive assets to each other, creating a harmonious business union', then at least the thesis smacks of common sense and not of special pleading. This is probably as good a book on the subject as you could convene in the last nine months. If it looks silly in a year's time, it will be for reasons beyond its scope. What price all those much-anthologised airline loyalty schemes after 11 September this year?

One neat development with Clicks, Bricks and Brands. It is a dual book, interactive, with each chapter trailing an updated web page wherein you can stay in touch with developments in that area. Now, that is smart - especially at a time when business books are inevitably becoming more newsletters than bibles. 


\section{An artistic bias; little new}

\section{Academic stance}

\section{A summary of theories}

\section{A good language guide}

\section{Innumerate}

\section{No depth}

\section{Relationship Marketing: Exploring Relational Strategies in Marketing}

John Egan

Financial Times/Prentice Hall, 2000; softback; 224pp; ISBN 0273646125; $£ 24.99$

According to the cover blurb, the author of this short book critically reviews and analyses what has been described as marketing's new paradigm. As a reviewer, the present writer must say that this book is disconcertingly uncritical of the theory that customers want relationships with organisations. In the preface the author admits to an artistic rather than an analytical bias, something that surely must be regarded as a weakness in a world of customer data. As for marketing's new paradigm, the reviewer found precious little connection with marketing, more with old-style consumerism, nor anything particularly new.

The stance of the author is resolutely academic. The student case exercises - what is your view of xyz? - place this firmly in the student essay-writing field. Every chapter shows a wealth of references to academic papers. However, the brevity of the book means that there is insufficient discussion of any source material for the student to gain more than a passing familiarity with the topics. It contains too little material for critical assessment of the subject by serious specialists.

Practising managers approaching the book are likely to find it pretty sterile. There are no attempts to give serious case studies, so the book comes across as a 200-page summary of various bodies of theory. It is extremely hard to relate these theories to real-life situations in a way that provides practical advice or guidance.

Jargon and buzzwords abound. The author is quite good at explaining the concepts in an abstract and introductory way. As a language guide for theoretical concepts the book is good.

What really gives away the book's presiding weakness is the chapter on relationship economics. This contains no numbers or data! As the author says, he is an arts person, but how absurd to even pretend to write a meaningful chapter on economics without data.

CRM too is really skimped over in a superficial fashion. While the author correctly acknowledges the database marketing origins of CRM, his innumeracy results in an anaemic explanation of the whole field. No serious attempt to discuss the mathematics, only a passing reference to the systems. Yet this whole area is all about data and their analysis, something the author does not pretend to understand.

The lack of depth is a major flaw. There is talk of 'service paradoxes' and 'puzzles'. In reality, there are no paradoxes in service, just poor analysis and bad logic. To understand customer relationships usually requires subtlety and depth of thinking, something this book lacks.

Particularly lacking is any attempt to represent adequately the vast wealth of knowledge we now have about consumer behaviour. This whole field is skimmed over with such superficiality that the uninitiated reader is left baffled by puzzles and paradoxes - because of the complacency of the writing and the weakness of the thinking. 


\section{Reviews}

Sound structure, but poor index

\section{A passable student introduction}

Structurally the book has some merit. The chapter structure leads the reader readily through the source material. However, its indexing is very poor - CRM is not even listed in the index.

In conclusion, the book is barely passable as an introduction for students wanting to write essays, and its structure lends itself to rote learning. It is not a book for business managers or advanced readers, who would be better served by one of Merlin Stone's many books in this area.

Robert Shaw Visiting Professor of Marketing, Cranfield School of Management 